\title{
Impact of Covid-19 on the survival of Igbo owned businesses in Nigeria: the nexus
}

\author{
Osita Fabian Chinedu ${ }^{1}$, Maduka Olisaemeka Dennis ${ }^{2}$, and Nkechi Chikwuemeka-Onuzulike ${ }^{3}$ \\ Department of Business Administration, Nnamdi Azikiwe University, Awka, Nigeria ${ }^{1,3}$ \\ Department of Economics, Nnamdi Azikiwe University, Awka, Nigeria ${ }^{2}$ \\ cf.osita@unizik.edu.ng ${ }^{l}$,od.maduka@unizik.edu.ng ${ }^{2}$,nf.onuzulike-chukwuemeka@unizik.edu.ng ${ }^{3}$
}

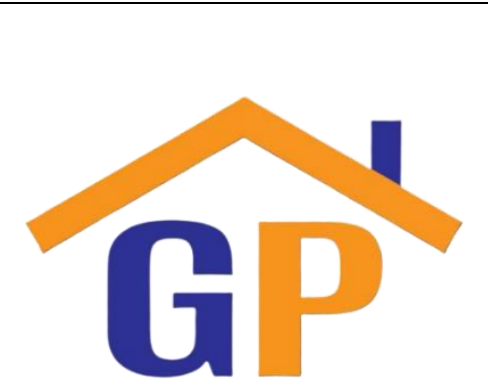

Article History

Received on 15 July 2020

$1^{\text {st }}$ Revision on 27 July 2020

$2^{\text {nd }}$ Revision on 28 July 2020

$3^{\text {rd }}$ Revision on 31 July 2020

Accepted on 3 August 2020

\begin{abstract}
Purpose: This study determined the impact of covid-19 on the survival of Igbo owned businesses in Nigeria.
\end{abstract}

Research methodology: The research adopted a survey research design. The population of the study was 50 , while census method was adopted. Source of data was questionnaire, which was tested for reliability using Split-Half technique and the value obtained was .863. The analysis was carried out using Regression Technique and a 5\% level of significance was used in the hypothesis test.

Result: Findings indicated that there is a relationship between restriction of movement and business sustainability $(r=.983)$ and the coefficient of determination shows that a $96 \%$ change in the sustainability of Igbo owned businesses is explained by changes in restriction of movement.

Limitations: The narrowing of the scope of the study to only importers of goods in Anambra state limits the generalizability of the study.

Contribution: Nigerian government will by this study know how to encourage businesses to survive after a pandemic such as covid19. Also, small business will gain from this study in that they will know from the suggestions made, how to navigate through tough times in their businesses by embracing online platforms to import or supply products.

Keywords: SMEs, Coronavirus, Business sustainability, Igbo owned businesses, Restriction of movement

How to cite: Chinedu, O. F., Dennis, M. O., \& ChikwuemekaOnuzulike, N. (2020). Impact of Covid-19 on the survival of Igbo owned businesses in Nigeria: the nexus. International Journal of Financial, Accounting, and Management. 2(2), 121-130.

\section{Introduction}

A viral wave known as coronavirus (Covid-19) is ravaging across the globe. It has truly exposed the fact that the world is a global village, as it swept across many countries of the world. It started in Wuhan, China at the end of 2019 and has continued to spread like wildfire across the world. McKibbin and Fernando (2020) state that the virus emerged in December 2019, in Wuhan city in Hubei province of China. The virus was declared a pandemic by the World Health Organization (WHO) on the $11^{\text {th }}$ March 2020, and since then, it has become a global emergency, given its impact on the world's population and economy. The spread of the virus has severely dealt with the global economy. It is uncertain when everything would come to normalcy. Succinctly capturing this, Tucker (2020) avers that the COVID-19 outbreak is likely to cause bankruptcy for many global firms as movements are restricted for both buyers and sellers. Similarly, Naveen and Anders (2020) posit that the virus has forced many businesses to close, leading to an unprecedented disruption of commerce in 
many sectors of different economies. As it stands presently, many nations of the world are still struggling to contain the spread of the virus and the impacts on their economy.

China being the epicentre of the pandemic has in recent decades become extremely important to the global economy. China's dominance in the global economy is related to its status in the area of production of consumer goods. As of today, most of the world's products are being imported from China (United Nations Conference on trade and development, 2020). A cut in the Chinese supply chain may affect the productive capacity and, therefore, Gross Domestic Product (GDP) of many countries. Most African Countries including Nigeria that depend largely on Chinese suppliers may face the shortage of critical components of their production segments. This is why it appears unavoidable that the novel Covid-19 Pandemic will have an impact on the economy of many nations of the world. Aifuwa, Musa and Aifuwa (2020) opine that the global economy is currently dealing with the reality of the COVID-19, which has led to monumental economic implications for exceeding number of businesses across the world.

Every country is, in terms of the law, said to be an independent unit, subordinate to none and its sovereignty is unlimited over all persons and association with its territorial limits. Nevertheless, no state can have an absolutely independent and secluded existence (Ndifreke \& Orifa, 2018). It is difficult for countries to survive without any form of exchange with another which involves the crossing breeding of ideas and technologies. As a result, because many nations depend on the production and supply capacity of China, every economy seems troubled by the outbreak and subsequent spread of the virus, occasioned by international and local lockdown(Tashanova, Sekerbay, Chen, Luo, Zhao \& Zhang, 2020). This is even more so with Nigeria who is import-dependent for all sorts of products and services from China and other countries.

A large proportion of Small and Medium Enterprises (SMEs) owners in Nigeria import most of their goods from China, European and Western countries. SMEs sector plays a dominant role in enhancing the standard of living of people as well as contributing to the Gross Domestic Products (GDP) of numerous economies (Paul, 2010; Ojeka \& Mukoro, 2011). Aremu and Adeyemi (2011)aver that SMEs play very important roles through the creation of industries/businesses for the economic sustainability of many nations. In Nigeria, SMEs provide up to fifty percent (50\%) of the employment generation and industrial output (Ayiro, 2004). A great number of these SMEs are either domiciled in the southeastern part of the country or owned by people from the region because of their industriousness. To lay credence to this, Orugun and Nafiu (2014) assert that Igbo entrepreneurs contribute significantly to the economic boom of Nigeria. Their business prowess is adjudged to have contributed to the increased standard of living of many Nigerians.

Having established the importance of businesses owned by south easterners of Nigeria or operating in the southeast, a study of this nature is deemed fit because of the impact covid-19 prevention strategy among which is movement restriction, has on the smooth operation of these businesses. The study, however, is narrowed down to the dealers of imported goods in five major markets in the southeast (Onitsha Main Market, New motor spare parts Market, New Tyre international Market, Iweka Electronics Market, Onitsha and Building Materials International Market) all situated in Onitsha, Anambra State, Nigeria. The narrowing down of the study was occasioned by the fact that Onitsha is the second domain of SMEs in Nigeria after Lagos and also, Anambra State is among the first states in Nigeria that placed restrictions on movement, closure of borders, partial closure and subsequent full closure of markets and ban on all sorts of gatherings to curtail the spread.

Before the spread of the virus, Igbo businesses contribute immensely to the economy of Nigeriathrough the payment of taxes, market levies and contribution to employment generation and GDP growth. They (Igbo businesses owners) survive by travelling from one part of the country to another to make purchases of products and supply the same to different parts of the country (Nigeria) and beyond. However, as a result of the movement restriction placed by both the Federal and State government, they appear unable to carry out their business dealings smoothly. They are no longer able to travel out to make purchases of goods as a result of the shutdown of international movements, 
neither are they able to make local and international supplies. These could have immense implication for the country as a whole as their contribution to the nation's GDP could be negatively affected, the employment generation contribution of the SMEs owned by this people could be reduced and could potentially throw the nation into recession. It is against this background that, the researchers consider the study on the impact of Covid-19 on the survival of Igbo owned businesses in Nigeria. Specifically, this study seeks to determine the effect of restrictions of movement on the sustainability of Igbo owned businesses in Nigeria.

\section{Conceptual and theoretical issues}

\subsection{The Igbo people and their ubiquitous businesses in Nigeria}

The Igbo people, occasionally referred to as Ibos are oriental people of Nigeria, with a population of about 40 million; approximately $24 \%$ of the total Nigeria population; they are the third-largest ethnic group in Nigeria(Obunike, 2016). Their indigenous language is also called Igbo. The native Igbo states in Nigeria are Anambra, Abia, Imo, Ebonyi and Enugu State. The Igbo people also occupy more than $25 \%$ of the population of Rivers and Delta States. Traces of them could also be found in some states like Cross Rivers, Akwa Ibom and Benue State.

The development of communities through business endeavours has always been the traits of the Igbo people. Chukwu (2015)opines that the Igbo's had at several times demonstrated a strong will to develop their society and economy. Her economy was majorly based on three sectors, mainly, agriculture, non-agricultural production and trade. They were said to have a high literacy rate more than other tribes in Nigeria, a factor which contributed to them occupying most of the strategic positions in Nigeria civil service before the Nigeria - Biafra War. It was the losses they incurred during and after the war that made most of them resort to buying and selling (Chukwu, 2015).

The contributions of the Igbo people in the Nigeria economy, host states and communities over the decades have attracted comments about their character and entrepreneurial spirit. In view of that, Olanrewaju (1999) in his paper: the Igbo Entrepreneur in the political economy of Nigeria says that the Igbo people, when compared to other major ethnic groups in Nigeria, dominates the entrepreneurial activities, especially in the areas of micro, small and medium enterprises. The distinctive characteristics the Igbo entrepreneurs have over others is the determination and perseverance with which they carry on despite civil war experiences and unfavourable economic policies meted on them.

Orugun and Nafiu (2014) reveal the research result conducted by an independent body, which shows that Igbo has $74 \%$ of the totality of investment in Lagos State, $5 \%$ by Hausa/Fulani, $15 \%$ by foreigners (Non-Nigerians), $5 \%$ by other Nigerian's tribe not mentioned above, then Yoruba, the aborigines of Lagos State owns only 1\%. The statistics also reveal that Igbo Investment in Lagos alone is not less than $\$ 300$ trillion, Abuja is about $\$ 600$ trillion, Kano and Kaduna states are over \#10 trillion respectively, while in far North like Borno, Yobe and Adamawa states are \$15 trillion ( $\$ 5$ trillion respectively). Then in Plateau state, it is over $\$ 15$ trillion (Orugun \& Nafiu, 2014). All these are pointers to the wonderful contribution of Igbo businesses in different parts of the country.

\subsection{Business sustainability}

The term sustainability is drawn from the word sustain which is subsumed from survive. Therefore, to be sustained means to survive. In the world of businesses, sustainability means staying relevant and competitive in the ever dynamic business environment. Therefore, when businesses can withstand challenges and the turbulence present in a typical business environment, that business is said to be sustainable. Ifekwem and Adedamola (2016) aver that SMEs are considered viable when they can surmount the bottlenecks that stand in their way in the internal and external business environment. Similarly, Nidumolu, Pralahad and Rangaswami (2009) opine that sustainability may become an integral part of the strategies of businesses that overcomes varying degrees of challenges inherent in the operational environment.

Ensuring that businesses continue operating profitably is the hallmark of sustainability. Supporting this assertion, Anekwe, Ndubusi-Okolo and Uzoezie (2019) state that business sustainability is about 
ensuring that businesses do not run out of needed resources. It means that development efforts including those by businesses and government should be such that does not jeopardize the ability of future generations of organizations and people to meet their needs (Wiser \& Magraw, 2005).

The concept of SME is one that has generated significant interest in the past. It has no single generally accepted definition; the definition depends on the country or the defining agency. But generally, every definition of SME is usually anchored on three constant factors which are the number of employees, total annual sales and value of net assets. According to the Central Bank of Nigeria as cited in Motilewa, Ogbari and Aka (2015), any SME operating in Nigeria must have a fixed capital or asset of between $\$ 5$ million and $\$ 500$ million and turnover of less than $\$ 100$ million per annum and labour force between 11 and 300 employees.

The sustainability of SMEs in different countries is essential because of the sterling role they play in employment generation and GDP contribution. Hence, government through different means try to support and improve their survival rate. Ifekwem and Adedamola (2016) aver that governments, particularly in developing countries make efforts to support the survival of SMEs through various policies. However, the extent to which these policies have affected the sustainability of SMEs is still relatively vague. Yet, their survival is further compounded by the onslaught brought the coronavirus pandemic.

\subsection{Coronavirus disease (Covid-19)}

Coronavirus Disease (Covid-19) is an infectious disease caused by a newly discovered coronavirus. The disease started in December 2019 in Wuhan, China. It was initially named as the 2019 novel coronavirus (2019-ncov). But on the 12th January 2020, the World Health Organization (WHO) officially named the disease as Coronavirus disease 2019 (Covid-19). Each of the letters seen in the name represents something. 'CO' stands for corona, 'VI' for virus, and 'D' for disease while the 19 is for the year 2019 when the virus was said to have emanated (Ojiagu, Nzewi \& Arachie, 2020). It is a highly infectious and pathogenic viral disease caused by severe acute respiratory syndrome coronavirus 2 (SARS - COV2).

The disease is transmitted basically through direct contact with respiratory droplets of an infected person, generated through coughing and sneezing, and touching surfaces contaminated with the virus. Commonest symptoms of the virus are Fever, Cough, Shortness of breath, sneezing. But in more severe cases, it could cause pneumonia or breathing difficulties, sepsis, muscular pain, septic shock (World Health Organization, 2020).

The WHO Situation Report - 73 on covid-19 provides a brief overview of available evidence on transmission of Covid-19 from the symptomatic, pre-symptomatic and asymptomatic mode of transmission.

(i) Symptomatic transmission: A symptomatic case/patient is a person who has developed signs and symptoms compatible with covid-19 virus infection. It can be transmitted from symptomatic patient to others who are in close contact with the infected person through respiratory droplets. The virus is highest in upper respiratory tracts like nose and throat in the first 3 days from onset of symptoms. It is more contagious in symptomatic patients.

(ii) Pre-symptoms transmission: This is the period between exposure to the virus and the period of developing symptom. It is also called the incubation period. This period is between the average of 5-6 days, at times can be up to 14 days. Some patients can be contagious during the pre-symptomatic period.

(iii) Asymptomatic transmission: The infected people under this category have the disease in them but do not develop symptoms. Asymptomatic transmission refers to transmission of the virus from a person, who does not manifest any of the symptoms. They are usually reported during contact tracing efforts. 
According to the United Nations Development Programme (2020) and WHO, 2020, the vaccine for Covid-19 is yet to be discovered and only preventive and precautionary measure to curtail the spread is suggested. These measures as put forward by these agencies include:

- $\quad$ Regular handwashing with soap and water or usage of alcohol-based hand sanitizer.

- $\quad$ Avoid touching of mouth, nose or eyes with your hands

- $\quad$ Adhere to social distancing measures

- $\quad$ Covering of mouth and nose with an elbow when coughing or sneezing,

- $\quad$ Use of facial mask.

\subsection{Restriction of movement order in Nigeria}

Restriction of movement order as it relates to Covid-19 prevention measures is a limitation of personal liberty to ensure health, safety and welfare of the citizenry. The only people exempted from the order are those on essential duties. These set of people include medical personnel, drivers conveying essential materials such as foodstuff, or essential service personnel like health officials, journalists and or security personnel enforcing the movement restriction order.

Before the outbreak of the virus in Nigeria, people were free to move from one part of the country to another without any form of restriction, however, following the global Covid-19 outburst and the increasing number of Covid-19 cases in Nigeria, the Nigerian government announced a restriction on movement order in the country as a measure to curb the outbreak. The restriction on movement orders include:

1. Ban on inter-state travel (except those on essential duties)

2. Ban on mass gatherings of people

3. Closure of markets, worship centres, social gathering, schools, offices etc.

All these measures put in place were to limit the spread of the virus from one state to another and to also limit community transmission of the disease. However, the extent to which the purpose of the order was achieved is still largely unknown in the country.

\section{Theoretical framework}

The study is anchored on the Need for Achievement Theory by David C. McClelland in 1961. This theory is nothing but a motivational theory that stands on the tripod of Achievement, Affiliation and Power. The theory states that every person or society has one of the three main driving motivations; the needs for achievement, affiliation and or power. These motivators are not natural; people develop them through their lifestyles. Achievers like to solve problems and achieve goals. According to Eboh (2002), the central focus of the theory is that individual or society with a high need for achievement also have an unquenchable thirst for success and would do everything to challenge their skills and creative activities to achieve that. That quest for achievement, and problem-solving drive, is what seemingly propels the Igbo people to establish and run businesses, and that marks the link between this study and the theory. Their business empires are propelled by the movement of goods and services from one location to another, something that has been seemingly negated by the restriction of movement order to curtail the further spread of covid-19. Therefore, the study hypothesizes that:

$\mathrm{H}_{\mathrm{a} 1}$ : Restriction of movement has an effect on the sustainability of Igbo owned businesses in Nigeria.

\section{Empirical evidence}

Ojiagu, Nzewi and Arachie (2020) evaluated the correlation between accountability and transparency on nation-building, using covid-19 experience as a yardstick. The study made use of survey research design. The population of the study consisted of 1174 employees of 5 ministries in Anambra State while the sample size determined using Taro Yamani formula was 298. Primary source of data collection was used which was questionnaire which was put through face and content validity to ascertain the validity of the study while Cronbach Alpha statistics for testing internal consistency of questionnaire was deployed and an average result obtained was 0.984 . The analysis of data technique was Regression Analysis at 5\% level of significance. It was revealed from the result that there is a statistically significant relationship existing between full disclosure and citizens improved trust ( $\mathrm{r}$ $=.984, \mathrm{R} 2=.899, \mathrm{~F}=1874.010, \mathrm{p}$-value $<0.05)$, and that there is a statistically significant relationship existing between impact reporting and citizens buy-in $(r=.947, \mathrm{R} 2=.897, \mathrm{~F}=1842.355$ 2020 | International Journal of Financial, Accounting, and Management/ Vol 2 No 2, 121-130 
p-value < 0.05). The study concluded therefore that there would be no trust issues between the governed and government if full disclosure and impact reporting have been the hallmark all the while. Following this, it was recommended among other things that Anambra State Anti-corruption Strategy (ANSACS) needs to do all it can to encourage various government ministries and agencies to engage more in full disclosure and impact reporting in the state.

The effect of Coronavirus pandemic outbreak on the performance of private businesses in Nigeria was examined by Aifuwa, Musa and Aifuwa (2020). In their study, a survey research design was adopted due to the nature of the work. The population of the study were made up of private businesses and financial analyst in Nigeria. However, the main target of the work were online business staff in Lagos State. To knock down the size of the population, a sample size of three hundred and eighty-four (384) was used. The major source of data was primary source through a structured questionnaire. The copies of questionnaire so used were distributed via an online medium to the owners of private businesses and financial analysts of interest in Lagos State, Nigeria. The reliability of the questionnaire used in the study was ascertained using linear regression. The result emanating from the analysis done in the study indicated that COVID- 19 pandemic negatively affect both the financial and non-financial performance of private businesses in Lagos state in particular and Nigeria at large. Sequel to this, the study concluded that that COVID-19 pandemic harms firm performance in Nigeria and recommended among other things that the government should include private businesses in its stimulus packages or palliatives programmes as this will help in keeping the businesses operational and afloat during this trying period.

In a study carried out by Orugun and Nafiu (2014) in Nigeria to investigate if the Igbo entrepreneurial activities are the remedy for the Nigerian economic growth and development and if the Igbo Trade Apprenticeship Model (ITAM) could be used to explain their exploits in various business endeavours. The study employed both primary and secondary source of data collection. The population of the study was 2,210,305 while the sample size arrived at using Taro Yamane sampling method was 400. Bowler's proportional allocation method was deployed in determining the copies of questionnaire that gets to where. Descriptive statistical tool, tables and Likert Scale method were used in analyzing the data collected through primary source. The findings from the study showed that the Igbo entrepreneurial activities are the panacea for the Nigerian economic growth and development and that ITAS is a business success factor among the Igbo people. Following these findings, it was concluded that the Igbo entrepreneurial activities are the panacea for the growth and development of Nigeria economically. Among other things, it was recommended by the study that Nigerians and the people of other emerging economies of the world emulate the Igbo entrepreneurship culture so as to develop economically and compete favourably with other nations.

Obunike (2016) did a study on the induction strategy of Igbo entrepreneurs and micro-business success in Nigeria. The population of the study covered the household equipment line of Main Market Onitsha in Anambra State, Nigeria. The source of data collection was questionnaire. A total of 300 questionnaire copies of the questionnaire were given out to the study sample (directors of the business or the Masters/Mistresses), out of which a total of 180 were returned, but 73 copies out of the returned copies were not used were invalid, making the researcher use 107 copies left for the analysis. The analysis deployed for the study included frequency tables, percentages, Pearson Product-Moment correlation analysis, and regression analysis. It was shown from the result that there is a strong positive nexus between the two variables tested. The study, therefore, recommended that the entrepreneurs should be supported and encouraged by the government through the provision of loans and adequate infrastructure that will aid their business.

Mbaegbu and Ekienaborhe (2018) researched Nigeria to determine the drivers of entrepreneurship among the Igbos of the South Eastern Geo-Political Zone. The study was a survey study with a focus on the five southeastern states with a sample size of 600 companies registered under the Corporate Affairs Commission from where 500 usable copies of questionnaire were analyzed using descriptive analyses and inferential statistics. Findings from the study showed that there were significant relationships between entrepreneurship and the three independent variables used in the study. It was 
concluded therefore that personality traits, cultural traits and environmental factors influence entrepreneurship and therefore drives the entrepreneurial tendencies of the Igbos in the studied zone.

\section{Research methodology}

The study adopted a survey research design. The study was carried out in Anambra State being one of the south-eastern states in Nigeria and the second hub of SMEs in Nigeria only behind Lagos. Data were collated through questionnaire which was tested for validity using face and content method while its reliability was assessed using Cronbach Alpha reliability test for internal consistency where an alpha level of .873 was obtained signalling a good consistency level. Data were collected from five major markets (Onitsha Main Market, New Motor Spare Parts Market, Iweka Electronics International Market, New Tyre International Market and Building Materials International Market) in Anambra state which are all situated in Onitsha being the commercial nerve centre of the state. These markets deal on imported goods from different part of the world, with China being the biggest country of import. A random selection of 50 importers (10 importers from each of the selected markets) was made. The entire population was studied because of their limited number. Sequel to this, a total of 50 copies of the questionnaire were distributed to the selected traders (importers), 46 copies were retrieved and used for the analysis. The analysis of data was carried out using mean for descriptive statistics and Regression Analysis for inferential statistics while hypothesis was tested at 5\% level of significance.

\section{Results and discussions}

Table 1: Distribution of responses for the impact of movement restriction on the sustainability of businesses

\begin{tabular}{|c|c|c|c|c|c|c|c|}
\hline $\mathbf{S} / \mathbf{N}$ & Questionnaire items & & & espons & e key & & \\
\hline & Restriction of movement items & $\mathbf{S A}$ & A & $\mathbf{U}$ & $\mathbf{D}$ & SD & Mean \\
\hline & & $(5)$ & $(4$ & 4) (3) & (2) & (1) & \\
\hline 1 & Customers from other states in Nigeria still come to buy from me. & 3 & 3 & 9 & 12 & 19 & 2.11 \\
\hline 2 & $\begin{array}{l}\text { Customers within Anambra State are the ones patronizing me in } \\
\text { this Covid-19 lockdown. }\end{array}$ & 15 & $1^{\prime}$ & 5 & 4 & 5 & 3.72 \\
\hline 3 & Goods I trade on are manufactured outside Nigeria. & 37 & 5 & 2 & 1 & 1 & 4.65 \\
\hline 4 & $\begin{array}{l}\text { I still have means of importing goods from outside Nigeria in this } \\
\text { Covid-19 lockdown. }\end{array}$ & 2 & 3 & 3 & 18 & 20 & 1.89 \\
\hline 5 & $\begin{array}{l}\text { Transportation of goods imported to my warehouse is not a } \\
\text { problem for me in this period. }\end{array}$ & 9 & 8 & 3 & 10 & 16 & 2.54 \\
\hline 6 & Restriction on movement causes low customer patronage. & 21 & 1 & 3 & 2 & 4 & 4.04 \\
\hline 7 & $\begin{array}{l}\text { Restriction on movement causes goods to stay longer than usual in } \\
\text { my shop/warehouse. }\end{array}$ & 19 & $1^{\prime}$ & 6 & 1 & 3 & 4.04 \\
\hline & Business suita & & & & & & \\
\hline 8 & Prices of goods are low because of low customer patronage. & 5 & 3 & 10 & 12 & 16 & 2.33 \\
\hline 9 & $\begin{array}{l}\text { Prices of goods are high because of the scarcity of goods in this } \\
\text { period, so people are afraid to buy in this period. }\end{array}$ & 18 & 14 & 5 & 6 & 3 & 3.83 \\
\hline 10 & Customers do not buy in large quantities any longer. & 11 & 19 & 7 & 2 & 7 & 3.54 \\
\hline 11 & $\begin{array}{l}\text { I do not import anymore, so I do not pay customs duties in this } \\
\text { covid-19 lockdown. }\end{array}$ & 26 & 14 & 2 & 2 & 2 & 4.30 \\
\hline 12 & I cannot pay some of my bills any longer. & 11 & 12 & 10 & 8 & 5 & 3.35 \\
\hline 13 & $\begin{array}{l}\text { I find it difficult to pay my employees/salespersons in this } \\
\text { period. }\end{array}$ & 12 & 11 & 10 & 7 & 6 & 3.35 \\
\hline
\end{tabular}


Table 1 above represents the responses of respondents on the effect of restriction of movement on the sustainability of businesses in the studied area. The table shows the frequencies in terms of the number of respondents that agreed or disagreed based on the individual questionnaire items. The analysis here is based on descriptive statistics using mean, with a threshold of acceptance of 3 and above. This implies that any questionnaire item with a mean of 3 and above should be accepted as playing out in the businesses of the respondents while the ones with a mean of less than 3 are rejected as not being true. From the analysis, it shows that questionnaire items 1, 4, 5 and 8 were rejected by the respondents, by virtue of their means being less than 3 while questionnaire items $2,3,6,7,9,10$, 11, 1213 and 14 are considered true as their means are above the threshold of 3 . By implication, the result shows that the respondents rejected that customers from other states in Nigeria still come to buy from them. Also, it shows that the respondents do not have a means of importing goods from outside Nigeria in this Covid-19 lockdown. Similarly, they also rejected that transportation of goods imported to their warehouses is not a problem for them in this period. They also rejected that prices of goods are low because of low customer patronage. This means that the Covid-19 protocol, chief among which is lockdown affect the importation, distribution and patronage of the business owners.

Going by the result as presented in Table 1 above, the respondents judging from the mean accepted that customers within Anambra State are the ones patronizing them in this Covid-19 lockdown. They also concurred that goods they trade on are manufactured outside Nigeria. It was also their view that restriction on movement causes low customer patronage. In the same line of thought, they agreed that restriction on movement causes goods to stay longer than usual in their shops/warehouses. On the sustainability part of the study, the respondents agreed that prices of goods are high because of the scarcity of goods in this period and that people are afraid to buy in this period. Also, they affirmed that customers do not buy in large quantities any longer owing to Covid-19. Also, respondents agreed that they do not import anymore, so they do not pay customs duties in this covid-19 lockdown, that they cannot pay some of their bills any longer, that they find it difficult to pay their employees/salespersons in this period and that they are running on a loss in this period of shutdown. All these responses point to the fact that the lockdown instituted by the government in a bid to curb the spread of the virus is affected the businesses of the respondents and could negatively impact on their sustainability.

\section{Test of Hypothesis}

Restriction of movement has an effect on the sustainability of Igbo owned businesses in Nigeria.

Table 2: Regression Model Summary

\begin{tabular}{|c|c|c|c|c|}
\hline Model & $\mathrm{R}$ & $\mathrm{R}$ Square & $\begin{array}{c}\text { Adjusted R } \\
\text { Square }\end{array}$ & $\begin{array}{c}\text { Std. Error of } \\
\text { the Estimate }\end{array}$ \\
\hline 1 & $.983^{\mathrm{a}}$ & .967 & .966 & 1.591 \\
\hline
\end{tabular}

a. Predictors: (Constant), ROFM

Source: Field Survey, 2020

Key

ROFM: Restriction Movement

Table 2 shows the regression result on the effect of restriction of movement on the sustainability of Igbo owned businesses in Nigeria. The result showed that there is a relationship between restriction of movement and business sustainability with a correlation coefficient of .983 while the coefficient of determination which shows the percentage change in business sustainability occasioned by restriction of movement is .966 showing that a $96 \%$ change in the sustainability of Igbo owned businesses is explained by changes in restriction of movement.

Table 3: ANOVA 


\begin{tabular}{|c|c|c|c|c|c|}
\hline Model & $\begin{array}{l}\text { Sum of } \\
\text { Squares }\end{array}$ & $\mathrm{df}$ & Mean Square & $\mathrm{F}$ & Sig. \\
\hline $\begin{array}{cc} & \text { Regression } \\
1 & \text { Residual } \\
& \text { Total }\end{array}$ & $\begin{array}{c}3236.779 \\
111.330 \\
3348.109\end{array}$ & $\begin{array}{c}1 \\
44 \\
45\end{array}$ & $\begin{array}{c}3236.779 \\
2.530\end{array}$ & 1279.248 & $.000^{\mathrm{b}}$ \\
\hline
\end{tabular}

a. Dependent Variable: BUSSUS

b. Predictors: (Constant), ROFM

Source: Field Survey, 2020

Key

BUSSUS: Business Sustainability

Table 3 shows the ANOVA result which determines if the relationship indicated in Table 2 above is statistically significant or whether it is by chance. This is measured by the probability value as represented in Table 3 as Sig. Comparing the Sig (significance) value (p-value) of .000 with the level of significance used in the study (.05), it shows that the obtained p-value is lesser than the level of significance used $(0.000<0.05)$, hence, the alternate hypothesis is accepted and it is stated that restriction of movements has a significant effect on the sustainability of Igbo owned businesses in Nigeria.

\section{Conclusion}

Coronavirus has brought in its wake destruction to lives and economies of nations because many people have died and economic activities have been shut down. Movement restriction was placed, and a ban on gathering implemented, thereby negating the performance of businesses. Tucker (2020) observed that with the outbreak of the virus, cases of businesses shutting down and filing for bankruptcy could escalate. Similarly, Naveen and Anders (2020)and Aifuwa, Musa and Aifuwa (2020) showed that there has been a monumental disruption in the free flow of businesses activities in globe owing to the spread of the virus. This is even more true for SMEs with little financial firepower and knowledge to automate and move operations online. Sequel to this as revealed by the analysis of the study, the sustainability of SMEs are hanging in the balance as not all will come out of this pandemic unscathed.

\section{Recommendation}

Following the findings of the study, it is recommended that:

a) The government needs to provide various business incentives to SMEs such as Tax rebate, suspended loan repayment and interest-free loans and stimulus packages to keep them afloat while the pandemic persists.

b) Businesses on their part should work hard to automate their operational processes to reduce cost, time and reduce contact with people.

\section{Limitations and Study Forward}

The generalizability of this study is limited by narrowing the scope of the study to only importers of goods in Anambra state. Also, using just 50 samples and questionnaire makes the inference power of the study limited.

\section{References}

Aifuwa, H. O., Musa, S., \& Aifuwa, S. A. (2020). Coronavirus pandemic outbreak and firms performance in Nigeria. Management and Human Resource Research Journal, 9(4), 15-25.

Anekwe R. I., Ndubusi-Okolo, P., \& Uzoezie, C. (2019). Sustainability in the Nigerian Business Environment: Problems and Prospects. International Journal of Academic Management Science Research, 3(3), 72-80.

Arenu, M. A \& Adeyemi, S. L (2011). Small and medium scale enterprises as a survival strategy for employment generation in Nigeria. Journal of Sustainable Development 4(1),56-72. 
Ariyo, D. (2004). Small firms are the backbone of the Nigeria Economy. African Economic Analysis, African Business Information Services, Brids north publication.

Chukwu, J. C. (2015) Traditional Igbo Economy: Challenges to growth and Development. Journal of Culture, Society and Development, 10, 70-77.

Eboh, F. E. (2002). Management Theory: Model for decision making computer villa. Publication, Enugu, Nigeria.

Ifekwem, N., \& Adedamola, O. (2016). Survival Strategies and Sustainability of Small and Medium Enterprises in the Oshodi-Isolo Local Government Area of Lagos State.ACTA University Sapientiae, Economics and Business, 4(2016), 103-118.

Mbaegbu, E., \& Ekienaborhe, E. (2018). The Drivers of Entrepreneurship among the Igbos of the South Eastern Geo-Political Zone of Nigeria. International Journal of Advanced Studies in Economics and Public Sector Management, 6(1), 49-62.

McKibbin, W., \& Fernando, R. (2020). The Global Macroeconomic Impacts of COVID-19: Seven Scenarios. Retrieved from https://researchgate.net

Motilewa, B. D., Ogbari, M., \& Aka, D. O. (2015). A Review of impacts of SMEs on Social Agents of economic liberations in Developing Economies. International Review of Management and Business Research, 4(3), $903-914$.

Naveen, D., \& Anders, G. (2020). Effects of COVID-19 on business and research. Journal of Business Research, 117(2020), 284-289.

Ndifere, S.N. \& Jacob A. Orita (2018). Nigeria Bilateral Trade Relations with China: An Assessment. International Journal of social sciences and Management Research, 4 (9).

Nidumolu, R., Pralahad, K.C., Rangaswami (2009). "Why Sustainability Is Now the Key Driver of Innovation", The Magazine, September.

Obunike, C. L. (2016). Induction Strategy of Igbo Entrepreneurs and micro-business success: A study of household equipment line, Main Market Onitsha, Nigeria. Acta University, Economics and Business, 4(2016), 43-65.

Ojeka, A. \& Mukoro O. O. (2011). International Financial reporting standard (IFRS) and SMEs in Nigeria; perceptions of academic. International Journal of Research in Commerce and Management, 2(1), 13-19.

Ojiagu, N. C., Nzewi, H. N., \& Arachie, A. E. (2020). Accountability and transparency in nationbuilding: a covid-19 experience in Sub-Saharan Africa. International Journal of Public Policy and Administration Research, 7(1), 23-33.

Olanrewaju, A. O. (1999). The Igbo entrepreneur in the political economy of Nigeria. Africa Study Monographs, 20(3), 147-174.

Orugiem J. J., \& Nafiu, A. T (2014). An exploratory study of Igbo Enterprises Activity and Business success in Nigeria as the Panacea for Economic growth and Development. International Journal of Scientific \& Technology Research, 3(9), 158-165.

Paul, P. (2010). Direction of standards for SMEs! IFRS for SMEs. International Accounting standards Boards Review, 2(1), 3-5.

Tashanova, D., Sekerbay, A., Chen, D., Luo, Y., Zhao, S. \& Zhang, Q. (2020). Investment opportunities an, $\mathrm{d}$ strategies in an era of coronavirus pandemic. Retrieved from https://ssrn.com/abstract=3567445

Tucker, H. (2020). Coronavirus bankruptcy tracker: These major companies are failing amid the shutdown. Forbeshttps://www.forbes.com/sites/hanktucker/2020/05/03/ coronavirusbankruptcy-tracker-these-major-companies-are-failing-amid-the- shutdown/\#5649f95d3425.

United Nations Conference on Trade \& Development (2020). Global trade impact of the coronavirus (Covid 19) Pandemic. Retrieved from https:IIwww.bbc.com> world

United Nations Development Programmes and World Health Organization (2020). Retrieved from https://www.undp.org/content/undp/en/home/coronavirus.html

Wiser, G. M., \& Magraw, D, B. (2005)Principles and Approaches of Sustainable Development and Chemicals Management for a Strategic Approach to International Chemicals Management (SAICM).https://www.ciel.org/Publications/SAICM_PrinciplesStudyFinal_July05.pdf

World Health Organization (2020). Novel Coronavirus (2019-nCoV): Situation Report-24, February 13, 2020 (https://www.who.int/docs/default-source/coronaviruse/situation-reports/20200213sitrep-24-covid-19.pdf?sfvrsn=9a7406a4_4). 